\title{
The Clinicopathological Characteristics of Androgen Receptor Splicing Variant 7 (AR-V7) Expression in Patients with Castration Resistance Prostate Cancer: A Systematic Review and Meta-Analysis
}

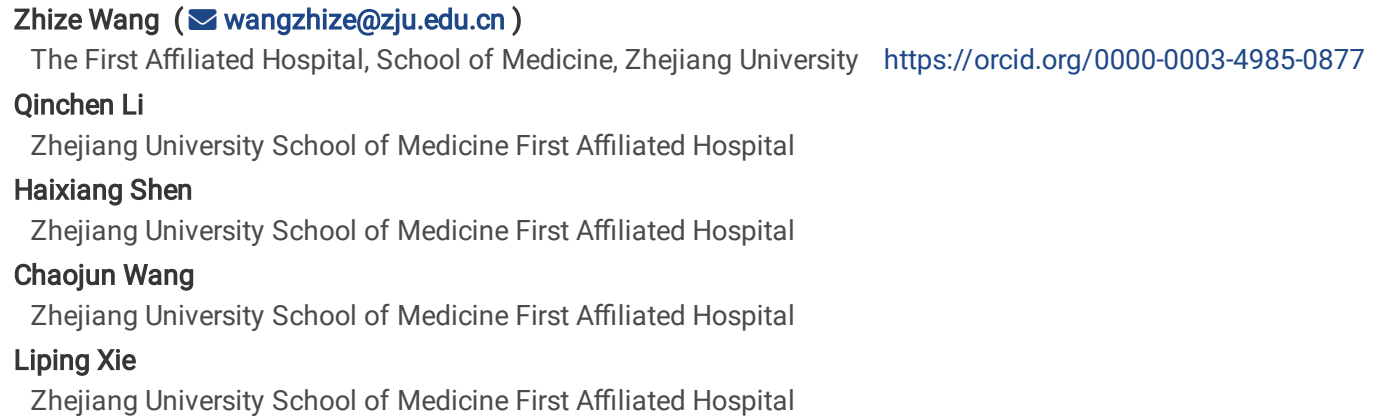




\section{Abstract}

BACKGROUND Accumulating studies indicate AR-V7 may be related to the poor prognosis of castration resistance prostate cancer (CRPC), while the evidence of the clinicopathological characteristics of $A R-V 7$ is rare.

METHODS To evaluate the clinicopathological features of AR-V7 in CRPC patients. A search of PubMed, Embase, and the Web of Science was performed using the keywords prostate cancer, prostate tumor, prostate neoplasm, prostate carcinoma; AR-V7, AR3, androgen receptor splicing variant-7, or androgen receptor-3. Twenty-four trials published due February 2020 were enrolled.

RESULTS The proportion of Gleason score $\geq 8$ was significantly higher in AR-V7-positive CRPC (69.5\%) than negative (54.9\%) (OR 1.68, 95\% Cl 1.25-2.25, $\mathrm{P}<0.001)$, while the rate of $\mathrm{T} 3 / \mathrm{T} 4$ stage (OR $1.16,95 \% \mathrm{Cl} 0.60-2.24, \mathrm{P}=0.65)$ and $\mathrm{N} 1$ stage $(\mathrm{OR} 0.99,95 \% \mathrm{Cl} 0.65-1.51, \mathrm{P}=0.96)$ were not statistically related to AR-V7 status. AR-V7-ositive patients had a significantly higher proportion of any site metastasis $(61.3 \%$ versus $35.0 \%)(\mathrm{OR} 2.19,95 \% \mathrm{Cl} 1.57-3.05, \mathrm{P}<0.001)$ and bone metastasis ( $81.7 \%$ versus $69.0 \%$ ) (OR 1.97, 95\% $\mathrm{Cl} 1.44-2.69, \mathrm{P}<0.001)$, and a trend close to significance was expected in visceral metastasis (28.8\% versus $22.1 \%$ ) (OR $1.29,95 \% \mathrm{Cl} 0.96-1.74, \mathrm{P}=0.09)$. The percentage of pain presence in AR-V7-positive CRPC (54.6\%) was prominently higher than negative (28.1\%) (OR 4.23, 95\% Cl 2.52-7.10, $\mathrm{P}<0.001$ ), line with worse ECOG performance status (56.7\% versus $35.0 \%, 0 R 2.18,95 \% \mathrm{Cl} 1.51-3.16, \mathrm{P}<0.001$ ). Limitations of the study include the differences in study sample size and design, AR-V7 detection assay, and disease characteristics.

CONCLUSIONS AR-V7 positivity was associated with higher Gleason score, bone or any site metastasis, presence of pain and worse ECOG performance score in CRPC, but not related to tumor stage or lymph node metastasis. More studies are needed to confirm these findings.

\section{Introduction}

Prostate cancer is the most common cancer among American men according to the recent study published in 2019 [1]. Unfortunately, most prostate cancer eventually experience progression to metastatic castration-resistant prostate cancer (mCRPC) [2, 3]. Predictive biomarkers are urgently warranted to identify the patients with worse prognosis and optimize more precise treatment selection. The androgen receptor (AR) signal pathway is the primary therapeutic target of prostate cancer because AR axis is still a major driver for tumor progression [4,5]. Either blocking AR [6, 7] or inhibiting ligand production [8,9] can suppress AR signaling and extends the survival of men with metastatic castration resistant prostate cancer (mCRPC). Whereas the appearance of Androgen receptor variants (AR-Vs), spliced isoforms of the AR and encode truncated AR proteins lacking the C-terminal ligand-binding domain but retaining the trans-activating $\mathrm{N}$-terminal domain, may lead to the AR signal based therapy resistance [10,11].

Accumulating evidence suggested that AR variant 7 (AR-V7), one of the most abundant AR-Vs in CRPC, are associated with prostate cancer aggressiveness, castration-resistant prostate cancer (CRPC) development $[4,12]$ and primary resistance to Enzalutamide and Abiraterone therapy in men with CRPC [13-15]. Despite incompetent to bind ligand, AR-V7 remains constitutively active in a ligand-independent manner and capable of driving CRPC growth [12, 16]. Therefore, AR-V7 may guide treatment decisions in CRPC patients and serve as a predictive biomarker [17, 18].

Although the prognosis value of AR-V7 has been revealed in CRPC, the clinicopathological characteristics of AR-V7 expression still remain unclear and controversial $[13,14,19-21]$. Some studies indicated AR-V7 positivity was associated with clinicopathological characteristics; however, others were not [13, 21-23]. To our knowledge, there is no systematic review investigating this topic which has been published so far and a meta-analysis is expected to a robust conclusion. Our study aimed to analysis the relation between AR-V7 expression and clinicopathological features including Gleason score, tumor stage, node stage, metastasis status, presence of pain and ECOG performance status score in CRPC. 24 studies were enrolled to evaluate the clinicopathological significance of AR-V7 expression in CRPC patients.

\section{Methods}

\subsection{Search strategy}

This meta-analysis was conducted in accordance with the Preferred Reporting Items for Systematic Reviews and Meta-Analyses (PRISMA) statement [24]. Search was completed before February 2020; published studies were retrieved from Embase, PubMed, and the Web of Science. Using prostate cancer or prostate neoplasm or prostate tumor or prostate carcinoma; AR-V7 or AR3 or androgen receptor splicing variant 7 or androgen receptor 3 as search terms. The references cited in the selected articles were also referred to identify more applicable studies. Two or three reviewers independently evaluated each study and identified whether they met the predefined inclusion criteria. Differences and disagreements in the studies that were selected were settled by discussion.

\subsection{Selection criteria}

Titles and abstracts of these searching studies were primarily screened and full papers were further retrieved to confirm eligibility. To be eligible, studies had to meet the following criteria. 1) The study reported on prostate cancer and AR-V7. 2) The results included the AR-V7 positive and patients' clinicopathological characteristics in castrated refractory prostate cancer (CRPC) including Gleason score, tumor $(\mathrm{T})$ stage, node $(\mathrm{N})$ stage, metastasis (M) status, presence of pain and/or Eastern Cooperative Oncology Group (ECOG) performance status score. 3) These outcomes were obtained from clinical trials, including prospective series or retrospective cohort studies or comparative series or case-series studies. Studies were excluded if they 1) only reported the AR-V7-positive proportion in hormone sensitive prostate cancer (HSPC) or other prostate neoplasm type; 2 ) did not report any clinicopathological features; or 3 ) were in vitro or animal studies. 4) were in languages other than English unless there is a translation. 5) Were case letters; reports; editorials; comments; and review papers. The most recent information was included in the analysis with longer follow-up and a larger patient population, when more than one report of a same trial was available. 


\subsection{Data collection and study quality}

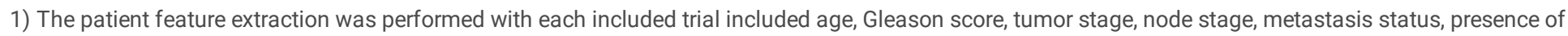

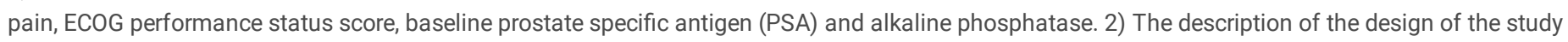

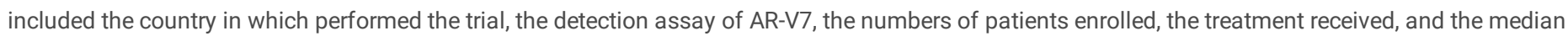

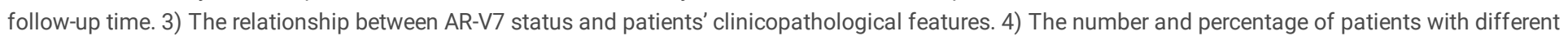
AR-V7 status in various groups of clinicopathological characteristics.

\subsection{Statistical methods}

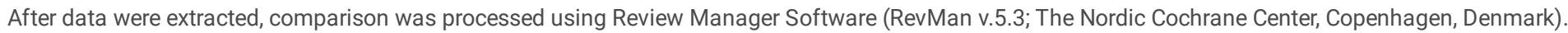

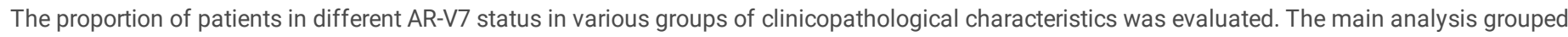

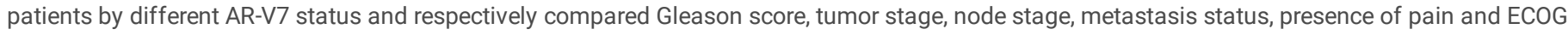

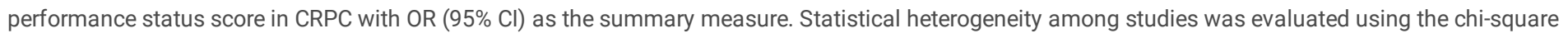

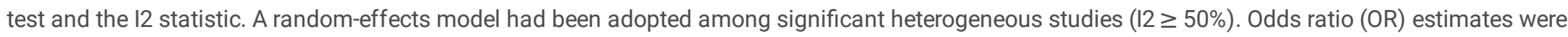

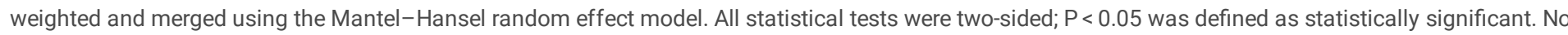
correction was made for multiple comparisons.

\section{Results}

\subsection{Trial characteristics and quality}

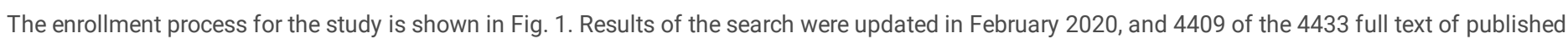

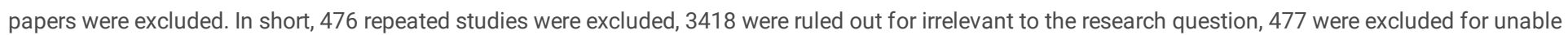

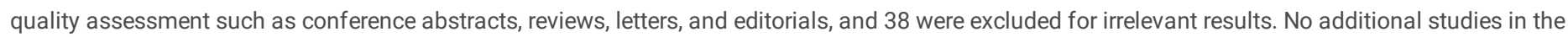
reference lists. A total of 24 studies were selected in the present meta-analysis.

\subsection{Patient characteristics}

Twenty-four trials enrolling 2431 patients were included in the clinicopathological features of AR-V7-positivity CRPC; their features were presented in Table 1. The target specimens and detection assays of AR-V7 were presented in Supplementary Table 1 in detail. Sixteen trials which enrolling 1699 patients were included in the Gleason score meta-analysis; six trials enrolling 169 patients in the T stage; ten trials enrolling 587 patients in the $\mathrm{N}$ stage; eighteen trials enrolling 1935 patients in the metastasis; a total of 418 patients were enrolled in the five trials in the presence of pain and seventeen trials enrolling 2047 patients were included in the ECOG performance status meta-analysis. 
Table 1

- Characteristics of studies included in the clinicopathological features of different AR-V7 status CRPC

\begin{tabular}{|c|c|c|c|c|c|c|c|c|c|c|c|}
\hline \multirow[t]{2}{*}{ Study } & \multirow[t]{2}{*}{ Year } & \multirow[t]{2}{*}{ Country } & \multirow{2}{*}{$\begin{array}{l}\text { Study } \\
\text { design }\end{array}$} & \multirow{2}{*}{$\begin{array}{l}\text { AR-V7 } \\
\text { detection } \\
\text { assay }\end{array}$} & \multicolumn{7}{|c|}{ Patients characteristics } \\
\hline & & & & & Treatment & $\begin{array}{l}\text { Patients } \\
\text { (n) }\end{array}$ & $\begin{array}{l}\text { Age } \\
{[42]}\end{array}$ & $\begin{array}{l}\text { Gleason } \\
\text { score } \\
(\%)\end{array}$ & $\begin{array}{l}\text { Tumor } \\
\text { stage at } \\
\text { diagnosis } \\
(\%)\end{array}$ & $\begin{array}{l}\text { Baseline } \\
\text { PSA } \\
\text { (ng/ml) } \\
\text { median } \\
\text { [42] }\end{array}$ & $\begin{array}{l}\text { Be } \\
\text { all } \\
\text { pr } \\
\text { (U }\end{array}$ \\
\hline \multirow[t]{3}{*}{ Antonarakis[14] } & 2017 & USA & prospective & CTC mRNA & $\mathrm{ABT}$ or ENZ & 53 CTC- & 70 & $\begin{array}{l}\geq 8 \\
(68.0 \%)\end{array}$ & - & 13.7 & $8 C$ \\
\hline & & & & & & $\begin{array}{l}\text { 113CTC+/ } \\
\text { AR-V7- }\end{array}$ & 71 & $\begin{array}{l}\geq 8 \\
(60.0 \%)\end{array}$ & - & 31.4 & 96 \\
\hline & & & & & & $\begin{array}{l}36 \text { CTC+1 } \\
\text { AR-V7+ }\end{array}$ & 70 & $\begin{array}{l}\geq 8 \\
(83.0 \%)\end{array}$ & - & 92.0 & 12 \\
\hline \multirow[t]{2}{*}{ Del Re [43] } & 2017 & Italy & prospective & $\begin{array}{l}\text { Exosomal } \\
\text { RNA }\end{array}$ & ENZ or ABT & 36 & 66 & $\begin{array}{l}\leq 7 \\
(44 \%)\end{array}$ & $\begin{array}{l}\mathrm{T} 1 / \mathrm{T} 2 \\
(8.0 \%)\end{array}$ & \multirow{2}{*}{$\begin{array}{l}26.3 \\
(0.63- \\
4581)\end{array}$} & \multirow{2}{*}{$\begin{array}{l}1 \varepsilon \\
(4\end{array}$} \\
\hline & & & & & & & 81) & $\begin{array}{l}\geq 8 \\
(53 \%)\end{array}$ & $\begin{array}{l}\text { T3/T4 } \\
(36.0 \%)\end{array}$ & & \\
\hline \multirow[t]{2}{*}{ Takeuchi T.[44] } & 2016 & Japan & cohort study & & ENZ or $\mathrm{ABT}$ & 43 & & $\begin{array}{l}\leq 7 \\
(20.9 \%)\end{array}$ & & \multirow{2}{*}{$\begin{array}{l}130 \\
(5.3- \\
9529)\end{array}$} & \\
\hline & & & & mRNA & & & $\begin{array}{l}(59- \\
88)\end{array}$ & $\begin{array}{l}\geq 8 \\
(72.1 \%)\end{array}$ & & & \\
\hline \multirow[t]{2}{*}{ Lee[45] } & 2016 & Korea & retrospective & $\mathrm{IHC}$ & ADT & 3 & 70 & $\geq 8$ & $\begin{array}{l}\text { T3/T4 } \\
(100 \%)\end{array}$ & \multirow{2}{*}{\multicolumn{2}{|c|}{$\begin{array}{l}8.78 \\
(8.6- \\
173.7)\end{array}$}} \\
\hline & & & & & & & $\begin{array}{l}(56- \\
70)\end{array}$ & & & & \\
\hline \multirow[t]{2}{*}{ Sharp[38] } & \multirow[t]{2}{*}{2019} & \multirow[t]{2}{*}{ USA } & \multirow[t]{2}{*}{ prospective } & \multirow[t]{2}{*}{$\mathrm{IHC}$} & \multirow{2}{*}{$\begin{array}{l}\text { ENZ or ABT, } \\
\text { Chemotherapy }\end{array}$} & \multirow[t]{2}{*}{160} & \multirow{2}{*}{$\begin{array}{l}68.5 \\
\text { IQR } \\
(63.9- \\
73.1)\end{array}$} & & $\begin{array}{l}\text { M1b } \\
(67 \%)\end{array}$ & \multirow{2}{*}{$\begin{array}{l}230.5 \\
\text { IQR } \\
(77.0- \\
591.5)\end{array}$} & \multirow{2}{*}{$\begin{array}{l}12 \\
(7\end{array}$} \\
\hline & & & & & & & & & $\begin{array}{l}\text { M1c } \\
(21 \%)\end{array}$ & & \\
\hline \multirow[t]{2}{*}{ Wang[46] } & \multirow[t]{2}{*}{2018} & \multirow[t]{2}{*}{ China } & \multirow[t]{2}{*}{ retrospective } & \multirow[t]{2}{*}{ CTC mRNA } & ENZ or ABT & 36 & 56.2 & & M0 (36\%) & & \\
\hline & & & & & & & 8.6) & & M1 (64\%) & & \\
\hline Tagawa [20] & 2019 & USA & prospective & CTC mRNA & $\begin{array}{l}\text { Docetaxel or } \\
\text { Cabazitaxel }\end{array}$ & 54 & $\begin{array}{l}71 \\
(53-\end{array}$ & $\begin{array}{l}\leq 6 \\
(13.7 \%)\end{array}$ & $\begin{array}{l}\mathrm{N} 1 \\
(51.9 \%)\end{array}$ & & $\begin{array}{l}21 \\
26\end{array}$ \\
\hline & & & & & & & & $\begin{array}{l}7 \\
(25.5 \%)\end{array}$ & $\begin{array}{l}\text { M1b } \\
(90.7 \%)\end{array}$ & $1558)$ & \\
\hline & & & & & & & & $\begin{array}{l}\geq 8 \\
(60.8 \%)\end{array}$ & $\begin{array}{l}\text { M1c } \\
(40.7 \%)\end{array}$ & & \\
\hline Antonarakis[13] & 2014 & USA & prospective & CTC mRNA & $\mathrm{ABT}$ & 31 & 69 & $\begin{array}{l}\leq 7 \\
(26.7 \%)\end{array}$ & $\begin{array}{l}\text { T1/T2 } \\
\text { (26.7\%) }\end{array}$ & & 11 \\
\hline & & & & & & & 79) & $\begin{array}{l}\geq 8 \\
(73.3 \%)\end{array}$ & $\begin{array}{l}\text { T3/T4 } \\
(61.3 \%)\end{array}$ & $2045.0)$ & \\
\hline & & & & & ENZ & 31 & 70 & $\begin{array}{l}\leq 7 \\
(40 \%)\end{array}$ & $\begin{array}{l}\mathrm{T} 1 / \mathrm{T} 2 \\
(54.8 \%)\end{array}$ & 44.3 & $1 \mathrm{C}$ \\
\hline & & & & & & & 84) & $\begin{array}{l}\geq 8 \\
(60 \%)\end{array}$ & $\begin{array}{l}\text { T3/T4 } \\
(45.2 \%)\end{array}$ & $3204.2)$ & \\
\hline Steinestel [47] & 2015 & Germany & prospective & CTC mRNA & ENZ or ABT & 24 & 75 & $\leq 7$ & - & 96.5 & - \\
\hline & & & & & & & $\begin{array}{l}(53- \\
87)\end{array}$ & $\begin{array}{l}\geq 8 \\
(58.7 \%)\end{array}$ & & $\begin{array}{l}(0.1- \\
4282)\end{array}$ & \\
\hline Nakazawa [22] & 2015 & USA & prospective & CTC mRNA & $\begin{array}{l}\text { NHT or } \\
\text { chemotherapy }\end{array}$ & 14 & 65 & $\begin{array}{l}\leq 7 \\
(92.9 \%)\end{array}$ & & $\begin{array}{l}58.7 \\
(2.2-\end{array}$ & 12 \\
\hline & & & & & & & $\begin{array}{l}(50- \\
82)\end{array}$ & $\begin{array}{l}\geq 8 \\
(0 \%)\end{array}$ & & & ל. \\
\hline Antonarakis[32] & 2015 & USA & prospective & CTC mRNA & $\begin{array}{l}\text { Docetaxel or } \\
\text { cabazitaxel }\end{array}$ & 37 & 67 & $\begin{array}{l}\leq 7 \\
(17 \%)\end{array}$ & $\begin{array}{l}\mathrm{T} 1 / \mathrm{T} 2 \\
(38.0 \%)\end{array}$ & 126 & $1 \epsilon$ \\
\hline & & & & & & & $\begin{array}{l}\left(40^{-}\right. \\
82)\end{array}$ & $\begin{array}{l}\geq 8 \\
(83 \%)\end{array}$ & $\begin{array}{l}\text { T3/T4 } \\
(62.0 \%)\end{array}$ & $2270)$ & ל \\
\hline
\end{tabular}

$\mathrm{IQR}=$ inter quartile range; $\mathrm{SD}=$ standard deviation; $\mathrm{AR}-\mathrm{V} 7=$ androgen receptor splice variant $7 ; \mathrm{CTC}=$ circulating tumor cell; $\mathrm{PSA}=$ prostate specific antigen; $\mathrm{AL}$ therapy; $\mathrm{NHT}=$ novel hormonal therapy; $\mathrm{LHRH}=$ luteinizing hormone releasing hormone $[\mathrm{PCa}=$ prostate cancer; $\mathrm{CRPC}=$ castration resistance prostate cancer; $f$ Enzalutamide; IHC = Immunohistochemistry; 


\begin{tabular}{|c|c|c|c|c|c|c|c|c|c|c|c|}
\hline \multirow[t]{2}{*}{ Study } & \multirow[t]{2}{*}{ Year } & \multirow[t]{2}{*}{ Country } & \multirow{2}{*}{$\begin{array}{l}\text { Study } \\
\text { design }\end{array}$} & \multirow{2}{*}{$\begin{array}{l}\text { AR-V7 } \\
\text { detection } \\
\text { assay }\end{array}$} & \multicolumn{7}{|c|}{ Patients characteristics } \\
\hline & & & & & Treatment & $\begin{array}{l}\text { Patients } \\
\text { (n) }\end{array}$ & $\begin{array}{l}\text { Age } \\
{[42]}\end{array}$ & $\begin{array}{l}\text { Gleason } \\
\text { score } \\
(\%)\end{array}$ & $\begin{array}{l}\text { Tumor } \\
\text { stage at } \\
\text { diagnosis } \\
(\%)\end{array}$ & $\begin{array}{l}\text { Baseline } \\
\text { PSA } \\
\text { (ng/ml) } \\
\text { median } \\
\text { [42] }\end{array}$ & $\begin{array}{l}\text { Ba } \\
\text { all } \\
\text { pr } \\
\text { (U }\end{array}$ \\
\hline Onstenk [48] & 2015 & Netherlands & prospective & CTC mRNA & Cabazitaxel & 29 & $\begin{array}{l}70 \\
(\mathrm{SD} \pm \\
7)\end{array}$ & - & - & $\begin{array}{l}321 \mathrm{IQR} \\
(76- \\
649)\end{array}$ & $\begin{array}{l}16 \\
(1\end{array}$ \\
\hline Zhang [49] & 2011 & USA & retrospective & $\mathrm{IHC}$ & ADT & 42 & $\begin{array}{l}63 \\
(42- \\
93)\end{array}$ & & & $\begin{array}{l}413.2 \\
(0.15- \\
7402)\end{array}$ & \\
\hline Saylor [50] & 2016 & USA & retrospective & RNA ISH & $\mathrm{ABT}$ or ENZ & 12 & & & & & \\
\hline Zadra [23] & 2019 & USA & retrospective & $\begin{array}{l}\text { Immune- } \\
\text { fluorescence }\end{array}$ & $\mathrm{ABT}$ or ENZ & 55 & 55 & & & & \\
\hline Belderbos [41] & 2019 & Netherlands & prospective & CTC mRNA & $\begin{array}{l}\text { ENZ, ABT or } \\
\text { Cabazitaxel }\end{array}$ & 94 & $\begin{array}{l}69 \text { IQR } \\
(65- \\
75)\end{array}$ & & & $\begin{array}{l}186 \text { IQR } \\
(67- \\
356)\end{array}$ & \\
\hline Cattrini [51] & 2019 & Italy & prospective & CTC mRNA & $\begin{array}{l}\text { ENZ, ABT or } \\
\text { Docetaxel }\end{array}$ & 39 & $\begin{array}{l}72 \\
(56- \\
84)\end{array}$ & & $\begin{array}{l}\text { M1b } \\
(79.5 \%) \\
\text { M1c } \\
(17.9 \%)\end{array}$ & $\begin{array}{l}35.2 \\
(0.33- \\
4688)\end{array}$ & \\
\hline Taplin [52] & 2019 & USA & prospective & CTC mRNA & $\begin{array}{l}\text { Galeterone or } \\
\text { ENZ }\end{array}$ & 953 & $\begin{array}{l}72 \\
(62- \\
77)\end{array}$ & $\begin{array}{l}\leq 7 \\
(43 \%) \\
\geq 8 \\
(57 \%)\end{array}$ & $\begin{array}{l}\text { M0 (58\%) } \\
\text { M1 (42\%) }\end{array}$ & $\begin{array}{l}15.5 \text { IQR } \\
(8.98- \\
31.70)\end{array}$ & \\
\hline Sharp [53] & 2019 & UK/USA & prospective & $\begin{array}{l}\text { CTC mRNA } \\
/ \mathrm{IHC}\end{array}$ & $\begin{array}{l}\text { ENZ, ABT or } \\
\text { Taxane }\end{array}$ & 95 CTC- & $\begin{array}{l}71.0 \\
\text { IQR } \\
(66.8- \\
75.6)\end{array}$ & & $\begin{array}{l}\text { M1b } \\
(74.7 \%) \\
\text { M1c } \\
(17.9 \%)\end{array}$ & $\begin{array}{l}110.0 \\
\text { IQR } \\
(29- \\
300.5)\end{array}$ & $\begin{array}{l}83 \\
(6\end{array}$ \\
\hline & & & & & & $\begin{array}{l}86 \mathrm{CTC}+ \\
\text { ARV7- }\end{array}$ & $\begin{array}{l}69.6 \\
\text { IQR } \\
(64.9- \\
72.3)\end{array}$ & & $\begin{array}{l}\text { M1b } \\
(86.1 \%) \\
\text { M1c } \\
(24.4 \%)\end{array}$ & $\begin{array}{l}147.0 \\
\text { IQR } \\
(51.0- \\
345)\end{array}$ & $\begin{array}{l}11 \\
(7\end{array}$ \\
\hline & & & & & & $\begin{array}{l}96 \mathrm{CTC}+ \\
\mathrm{ARV}+\end{array}$ & $\begin{array}{l}70.4 \\
\text { IQR } \\
(65.3- \\
74.6)\end{array}$ & & $\begin{array}{l}\text { M1b } \\
(84.4 \%) \\
\text { M1c } \\
(24.0 \%)\end{array}$ & $\begin{array}{l}244.5 \\
\text { IQR } \\
(109.3- \\
746.8)\end{array}$ & $\begin{array}{l}18 \\
(9: \\
34\end{array}$ \\
\hline Maillet [54] & 2019 & France & prospective & CTC mRNA & $\mathrm{ENZ}$ or $\mathrm{ABT}$ & 41 & 73 & $\begin{array}{l}\geq 8 \\
(56 \%)\end{array}$ & M1 (29\%) & 35 & \\
\hline Okegawa [55] & 2018 & Japan & retrospective & CTC mRNA & ENZ or $A B T$ & 49 CTC- & 69 & $\begin{array}{l}\geq 8 \\
(81.6 \%)\end{array}$ & & 75.7 & 31 \\
\hline & & & & & & $\begin{array}{l}23 \mathrm{CTC}+ \\
\text { AR-V7- }\end{array}$ & 71 & $\begin{array}{l}\geq 8 \\
(91.3 \%)\end{array}$ & & 71.5 & 32 \\
\hline & & & & & & $\begin{array}{l}26 \mathrm{CTC}+ \\
\mathrm{AR}-\mathrm{V} 7+\end{array}$ & 72 & $\begin{array}{l}\geq 8 \\
(96.2 \%)\end{array}$ & & 79.1 & 37 \\
\hline Chung [19] & 2019 & USA & prospective & CTC mRNA & ENZ or $A B T$ & 37 & $\begin{array}{l}72 \\
(67- \\
79)\end{array}$ & $\begin{array}{l}\leq 7 \\
(43.2 \%) \\
8(8.1 \%) \\
\geq 9 \\
(46 \%)\end{array}$ & $\begin{array}{l}\text { N1 } \\
(64.9 \%) \\
\text { M1b } \\
(89.2 \%) \\
\text { M1c } \\
(27 \%)\end{array}$ & $\begin{array}{l}20.9 \text { IQR } \\
(11.6- \\
96.8)\end{array}$ & $\begin{array}{l}10 \\
(8\end{array}$ \\
\hline Sieuwerts [56] & 2019 & Netherlands & prospective & CTC mRNA & Cabazitaxel & 52 & $\begin{array}{l}69 \\
(\mathrm{SD}= \\
7)\end{array}$ & & & $\begin{array}{l}209 \text { IQR } \\
(72- \\
510)\end{array}$ & $\begin{array}{l}17 \\
(9\end{array}$ \\
\hline
\end{tabular}

$\mathrm{IQR}=$ inter quartile range; $\mathrm{SD}=$ standard deviation; $\mathrm{AR}-\mathrm{V} 7$ = androgen receptor splice variant $7 ; \mathrm{CTC}=$ circulating tumor cell; $\mathrm{PSA}=$ prostate specific antigen; $\mathrm{AC}$ therapy; $\mathrm{NHT}=$ novel hormonal therapy; $\mathrm{LHRH}=$ luteinizing hormone releasing hormone $\mathrm{PCa}=$ prostate cancer; $\mathrm{CRPC}=$ castration resistance prostate cancer; $f$ Enzalutamide; IHC = Immunohistochemistry; 


\begin{tabular}{|c|c|c|c|c|c|c|c|c|c|c|c|}
\hline \multirow[t]{2}{*}{ Study } & \multirow[t]{2}{*}{ Year } & \multirow[t]{2}{*}{ Country } & \multirow{2}{*}{$\begin{array}{l}\text { Study } \\
\text { design }\end{array}$} & \multirow{2}{*}{$\begin{array}{l}\text { AR-V7 } \\
\text { detection } \\
\text { assay }\end{array}$} & \multicolumn{7}{|c|}{ Patients characteristics } \\
\hline & & & & & Treatment & $\begin{array}{l}\text { Patients } \\
\text { (n) }\end{array}$ & $\begin{array}{l}\text { Age } \\
\text { [42] }\end{array}$ & $\begin{array}{l}\text { Gleason } \\
\text { score } \\
(\%)\end{array}$ & $\begin{array}{l}\text { Tumor } \\
\text { stage at } \\
\text { diagnosis } \\
\text { (\%) }\end{array}$ & $\begin{array}{l}\text { Baseline } \\
\text { PSA } \\
\text { (ng/ml) } \\
\text { median } \\
\text { [42] }\end{array}$ & $\begin{array}{l}\mathrm{Be} \\
\mathrm{all} \\
\mathrm{pl} \\
(\mathrm{U}\end{array}$ \\
\hline
\end{tabular}

\begin{tabular}{|c|c|c|c|c|c|c|c|c|c|}
\hline \multirow[t]{3}{*}{ El-Heliebi [21] } & \multirow[t]{3}{*}{2018} & Austria & prospective & CTC FISH & $\begin{array}{l}\text { ENZ, ABT or } \\
\text { Taxane }\end{array}$ & 31 & \multirow{3}{*}{$\begin{array}{l}70.5 \\
(42- \\
83)\end{array}$} & $\begin{array}{l}\leq 7 \\
(38.7 \%)\end{array}$ & $\begin{array}{l}\mathrm{T} 1 / \mathrm{T} 2 \\
(22.6 \%)\end{array}$ \\
\hline & & Seiniay & & & & & & $\geq 8$ & T3/T4 \\
\hline & & Netherlands & & & & & & & $(45.2 \%)$ \\
\hline
\end{tabular}

$\mathrm{IQR}=$ inter quartile range; $\mathrm{SD}=$ standard deviation; $\mathrm{AR}-\mathrm{V7}$ = androgen receptor splice variant 7; $\mathrm{CTC}=$ circulating tumor cell; $\mathrm{PSA}=$ prostate specific antigen; $\mathrm{AC}$ therapy; $\mathrm{NHT}=$ novel hormonal therapy; $\mathrm{LHRH}=$ luteinizing hormone releasing hormone $\mathrm{PCa}=$ prostate cancer; $\mathrm{CRPC}=\mathrm{castration}$ resistance prostate cancer; $\mathrm{t}$ Enzalutamide; IHC = Immunohistochemistry;

\subsection{Gleason score}

The proportion of Gleason scores $\geq 8$ between the group of AR-V7-positive and negative CRPC was compared in sixteen studies including 1699 patients. As shown in Fig. 2, 242 of 348 (69.5\%) AR-V7-positive men had Gleason scores $\geq 8$, whereas 742 of 1351 (54.9\%) AR-V7-negative men were Gleason scores $\geq 8$. Gleason score was significantly higher in AR-V7-positive than in AR-V7-negative CRPC (OR 1.68, 95\% Cl 1.25-2.25, P<0.001). Significant heterogeneity was not found among studies $(12=0.0 \%, P=0.57)$ and fixed-effects model was adopted.

\subsection{T stage}

The rate of higher tumor stage (T3/T4) in different AR-V7 status CRPC was analyzed in six studies, 169 patients. Figure $3 \mathrm{~A}$ presented that 39 of 74 (52.7\%) AR-V7-positive men had higher T stage, and the proportion in AR-V7-negative CRPC was $49.5 \%$ (47 of 95). There was no significant difference of T stage in CRPC grouped by different AR-V7 status (OR 1.16, 95\% $\mathrm{Cl} 0.60-2.24, \mathrm{P}=0.65)$. There is no evidence for heterogeneity between the studies $(I 2=28 \%, \mathrm{P}=0.23)$ and fixed-effects model was applied.

\section{$3.5 \mathrm{~N}$ stage}

Lymph node metastatic rate was evaluated in ten studies including 587 CRPC patients, grouped by AR-V7-positive and negative. As shown in Fig. 3B, 104 of 283 (36.7\%) AR-V7-positive men had lymph node invasion, and the rate in AR-V7-negative CRPC was $28.0 \%$ ( 85 of 304 ). There was no significant difference of $\mathrm{N}$ stage in CRPC of different AR-V7 status (OR $0.99,95 \% \mathrm{Cl} 0.65-1.51, \mathrm{P}=0.96)$. Significant heterogeneity was not found $(\mathrm{I} 2=46 \%, \mathrm{P}=0.07)$ and fixed-effects model was used.

\subsection{M stage}

The proportion of metastases was assessed in ten studies including 1448 CRPC patients, grouped by different AR-V7 status. As shown in Fig. 4 A, 144 of 235 (61.3\%) AR-V7-positive men had metastases, while the rate in AR-V7-negative CRPC was 35.0\% (424 of 1213). The rate of metastases in AR-V7-positive CRPC was significantly higher than that in AR-V7-negative (OR 2.19, 95\% $\mathrm{Cl} 1.57-3.05, \mathrm{P}<0.001)$. Fixed-effects model was applied to evaluate $0 \mathrm{R}$ and $95 \% \mathrm{Cl}$ due to there is no heterogeneity between the studies $(12=3 \%, \mathrm{P}=0.41)$.

We further compared the proportion of bone metastases between the group of AR-V7-positive and negative CRPC in seventeen studies including 1935 patients. Figure 4B indicated that 375 of 459 (81.7\%) AR-V7-positive men had bone metastases, whereas the rate in AR-V7-negative was 69.0\% (1018 of 1476). Significantly higher rate of bone metastases was determined in AR-V7-positive CRPC (OR 1.97, 95\% Cl 1.44-2.69, P<0.001). Significant heterogeneity was not found $(I 2=21 \%, P=0.22)$, and a fixed effect model was performed to calculate the $\mathrm{OR}$ and $95 \% \mathrm{Cl}$.

Meanwhile, the visceral metastatic ratio was also evaluated in eighteen studies including 1137 CRPC patients, grouped by different AR-V7 status. Figure 4C indicated that 124 of 430 (28.8\%) AR-V7-positive men had visceral metastases and 156 of 707 (22.1\%) AR-V7-negative had visceral metastases. There was a barely detectable statistically significant difference of visceral metastatic ratio in different AR-V7 status $(O R=1.29,95 \% \mathrm{Cl} 0.96-1.74, \mathrm{P}=0.09)$. No significant study heterogeneity was detected $(I 2=19 \%, P=0.24)$ and fixed-effects model was adopted.

\subsection{Presence of pain}

The proportion of presence of pain was compared in five studies including 418 CRPC patients, grouped by different AR-V7 status. As shown in Fig. $5 A$, 59 of 108 (54.6\%) AR-V7-positive men suffered pain, while the rate in AR-V7-negative CRPC was $28.1 \%$ (87 of 310). Significantly higher rate of presence of pain was 
determined in AR-V7-positive CRPC (OR 4.23, 95\% Cl 2.52-7.10, $\mathrm{P}<0.001)$. Fixed-effects model was used to calculate OR and $95 \% \mathrm{Cl}$ because there is no heterogeneity between the studies $\left(I^{2}=0 \%, P=0.68\right)$.

\subsection{ECOG performance status score}

In total, seventeen trials 2047 CRPC patients were enrolled in the comparison of the relation between high ECOG score (ECOG score $\geq 1)$ and AR-V7 status. Figure 5B showed 275 of 485 (56.7\%) AR-V7-positive men were ECOG score $\geq 1$, whereas the rate in AR-V7-negative was 35.0\% (546 of 1562). AR-V7-positive CRPC patients had performed significantly higher ECOG score than AR-V7-negative (OR $2.18,95 \% \mathrm{Cl} 1.51-3.16$, $\mathrm{P}<0.001)$. A random effects model was used to calculate the $\mathrm{OR}$ and $95 \% \mathrm{Cl}$ because significant heterogeneity was found $(I 2=40 \%, \mathrm{P}=0.05)$.

\section{Discussion}

We processed a meta-analysis to verify the hypothesis that AR-V7 positivity was associated with worse clinicopathological features. Biomarker of clinical utility should provide reliable information to the doctors with the potential to optimize precision treatment for patients. AR-V7 is taken for the most common AR splice variant, which was first found in advanced stage patients [25-29]. AR-V7 positive may be a particular type of prostate cancer subtype due to its worse clinicopathological characteristics. As various researches have indicated that AR-V7 was a novel AR splice variant which was capable of initiating and promoting CRPC progress $[6,7,9]$, the AR-V7 positive CRPC needs to be considered as a novel subtype of CRPC with specific clinicopathological characteristics and resistance to AR signal targeted therapy.

AR-V7 positive has been associated with unfavorable baseline characteristics; therefore, it may reflect a larger neoplasm burden [20, 30, 31]. We compared the association between Gleason score and different AR-V7 status. Gleason score was obviously higher in AR-V7-positive than negative CRPC. We concluded that AR-V7 status is associated with clinicopathological characteristics for CRPC patients. However, recent trials showed insignificant relation between AR-V7positive and higher Gleason score [14], some even implied AR-V7-negative patients had higher Gleason score [13]. Our results indicated AR-V7 positive patients had significant higher Gleason score, which was inconsistent with the previous findings that AR-V7 positivity was not related to higher Gleason score in metastatic CRPC [13]. Further researches about the relation between AR-V7 and Gleason score are still urgently expected.

Recent researches indicated that AR-V7-positive men would suffer higher T stage and lower N stage respectively [20, 21]. In this analysis, we assess the relevance between AR-V7 expression and clinicopathological features of CRPC patients. According to the merged results, we offered trustworthy evidence that the correlations between AR-V7 with T stage and lymph node metastasis were not statistically significant.

Bone or any site metastasis, presence of pain and ECOG performance score were compared in CRPC respectively with different AR-V7 status. AR-V7-positive patients had an elevated risk of any site metastasis, pain sufferance and worse ECOG performance score compared with AR-V7-negative CRPC. Although there were few studies about the clinicopathological features of AR-V7, it has been a hot-spot role of clinical decision-making and potential therapeutic target of CRPC. Existing evidence validated that expression of AR-V7 protein in circulating tumor cells nuclear was related with superior survival on taxane therapy in clinical practice as a specific treatment biomarker in men with mCRPC [18]. Accordingly, AR-V7 targeted therapy strategies are necessary and AR-V7 should be continuously surveilled during treatment. Same conclusion as before, AR-V7 is related to faster disease progression in CRPC [32-35]. Considering the prognosis value and the specific clinicopathological characteristics of AR-V7 in CRPC, AR-V7-positive CRPC should be taken as a novel subtype of prostate cancer which requires more aggressive, personalized and AR-V7 targeted therapy strategy. Further prospective studies are certainly needed to validate the role of AR-V7 positive as a particular type of prostate cancer subtype in CRPC.

There are several advantages in our systematic review. First of all, this is the first meta-analysis that indicates the clinicopathological characteristics of AR-V7 in CRPC patients to our knowledge. Second, our research offers a scientific basis to support for individualized estimations of clinicopathological features for CRPC patients, identifies more aggressive CRPC patients. In this way, doctors may conduct precision medicine and individualized treatment for CRPC patients. A challenge in the near future will be to correctly classify patients according to AR-V7 status within a suitable time for clinical practice [36]. In addition, this study may promote researchers to design additional clinical studies with larger sample sizes to validate these findings.

Notably, we did the best to perform this meta-analysis but there were still a few limitations in this systematic review. The sample size is rather small and limits its statistical power, which ranged from 3 to 953 participants. And the number of published studies was not sufficiently large for more accurate results due to the limited number of studies included. It is certain that smaller sample sizes were less reliable and tended to have publication bias. Thus, more large-cohort clinical trials are warranted to more accurate provide evidence for the clinicopathological features in CRPC patients. Second, the standards of study designs were not unified. Many studies caused an uncertain selection bias due to enrolled patients from a single center. Others reported patients in single or multicenter clinical trials, where patients enrolled might be highly selected by different criteria. Third, only references published in English were included in our meta-analysis. Fourth, the cut-off values distinguishing positive and negative AR-V7 expression differed in studies. And the various detection assays and antibodies used in the included researches might impact the sensitivity and specificity of AR-V7 positivity [37-40]. Therefore, consensus on the analytical method of testing and cut-off value are needed [41], generalized to more large multicenter researches, will provide more precise and credible results. Moreover, the clinicopathological features of CRPC patients including T stage, N stage and M stage, the definition of PSA and alkaline phosphatase response, and Gleason score vary among different studies, which might be responsible for the heterogeneity. Last but not the least, we admitted that AR-V7 was not extensively and sufficiently studied in CRPC patients, which would most likely draw controversial conclusions.

Several important efforts we made to deal with these drawbacks. Firstly, we performed a comprehensive, systematic, and repeatable search strategy for the most relevant references in multiple online databases which based on the Preferred Reporting Items for Systematic Reviews and Meta-Analyses (PRISMA) statement. To be honest, selection bias couldn't be eliminated, but could be minimized by our strict screening of inclusion eligibility in the meta-analysis. Secondly, details of the study design, method of AR-V7 detection, types of therapy, Gleason score, tumor stage, node stage, metastasis status, presence of 
pain and ECOG performance status score in CRPC, and follow-up period were tabulated and available for further analysis and reference. Thirdly, fixed or random effect model was arranged according to different heterogeneity for more authentic and credible results. Additionally, the publication bias was evaluated and small-study effect was assessed by funnel plot listed in the supplement.

\section{Conclusions}

In conclusion, this meta-analysis clearly indicated that AR-V7 expression was significantly associated with Gleason score, bone or any site metastasis, pain presence and ECOG performance status, but not statistically related to tumor stage or lymph node metastasis. Specific clinicopathological features of AR-V7postive CRPC were expected with higher Gleason score, more metastasis and pain presence, and worse ECOG performance status. Considering the prognostic value of $A R-V 7$ in resistance to Abiraterone and Enzalutamide treatment for CRPC patients, our results may guide clinicians in identifying patients with more aggressive cancers, and selecting suitable patients that would derive durable clinical benefit from more active anti-tumor therapy. However, heterogeneous among study sample size and design, assays for AR-V7 detection assessment, and cut-off values definition for positive versus negative expression were evident within the included studies. More cross-institutional large-cohort prospective studies are warranted to confirm these findings and the clinical utility of AR-V7 as a biomarker in CRPC are expected.

\section{Abbreviations}

AR-V7: Androgen receptor splicing variant 7

CRPC: Castration resistance prostate cancer

mCRPC: Metastatic castration-resistant prostate cancer

AR: Androgen receptor

PRISMA: Preferred Reporting Items for Systematic Reviews and Meta-Analyses

T: Tumor

$\mathrm{N}$ : Node

M: Metastasis

ECGO: Eastern Cooperative Oncology Group

HSPC: Hormone sensitive prostate cancer

PSA: Prostate specific antigen

OR: Odds ratio

Cl: Confidence interval

IQR: Inter quartile range

SD: Standard deviation

CTC: Circulating tumor cell

ADT: Androgen deprivation therapy

NHT: Novel hormonal therapy

LHRH: Luteinizing hormone releasing hormone

PCa: Prostate cancer

ABT: Abiraterone

ENZ: Enzalutamide

IHC: Immunohistochemistry;

\section{Declarations}

\section{Availability of data and materials}

The datasets used and/or analysed during the current study are available from the corresponding author on reasonable request. 


\section{Acknowledgment}

We appreciate the technical supports of laboratory members.

\section{Funding}

None.

\section{Authors' contributions}

Project administration: ZW. Data curation: HS. Formal analysis: CW. Writing original draft: QL. Investigation: ZW. Writing revised: ZW and LX. All authors read and approved the final manuscript.

\section{Ethics Statement}

The studies involving human participants were reviewed and approved by First Affiliated Hospital of Zhejiang University.

\section{Consent for publication}

All authors have authorized the publication of this manuscript.

\section{Conflicts of interest}

Authors declare no conflicts of interest in this study.

\section{Funding support}

There was no funding source for this review. All authors had full access to all the data and the corresponding author had final responsibility for the decision to submit for publication.

\section{References}

1. Siegel RL, Miller KD, Jemal A: Cancer statistics, 2019. CA Cancer J Clin 2019, 69(1):7-34.

2. Ylitalo EB, Thysell E, Thellenberg-Karlsson C, Lundholm M, Widmark A, Bergh A, Josefsson A, Brattsand M, Wikstrom P: Marked response to cabazitaxel in prostate cancer xenografts expressing androgen receptor variant 7 and reversion of acquired resistance by anti-androgens. Prostate 2020, 80(2):214-224.

3. Paller CJ, Antonarakis ES: Management of biochemically recurrent prostate cancer after local therapy: evolving standards of care and new directions. Clin Adv Hematol Oncol 2013, 11(1):14-23.

4. Erb HHH, Sparwasser P, Diehl T, Hemmerlein-Thomas M, Tsaur I, Jungel E, Sommer U, Baretton GB, Haferkamp A, Neisius A et al: AR-V7 Protein Expression in Circulating Tumour Cells Is Not Predictive of Treatment Response in mCRPC. Urologia internationalis 2020:1-10.

5. Galletti G, Leach BI, Lam L, Tagawa ST: Mechanisms of resistance to systemic therapy in metastatic castration-resistant prostate cancer. Cancer treatment reviews 2017, 57:16-27.

6. Beer TM, Armstrong AJ, Rathkopf DE, Loriot Y, Sternberg CN, Higano CS, Iversen P, Bhattacharya S, Carles J, Chowdhury S et al: Enzalutamide in metastatic prostate cancer before chemotherapy. N Engl J Med 2014, 371(5):424-433.

7. Scher HI, Fizazi K, Saad F, Taplin ME, Sternberg CN, Miller K, de Wit R, Mulders P, Chi KN, Shore ND et al: Increased survival with enzalutamide in prostate cancer after chemotherapy. The New England journal of medicine 2012, 367(13):1187-1197.

8. Ryan CJ, Smith MR, de Bono JS, Molina A, Logothetis CJ, de Souza P, Fizazi K, Mainwaring P, Piulats JM, Ng S et al: Abiraterone in metastatic prostate cancer without previous chemotherapy. NEngl J Med 2013, 368(2):138-148.

9. de Bono JS, Logothetis CJ, Molina A, Fizazi K, North S, Chu L, Chi KN, Jones RJ, Goodman OB, Jr., Saad F et al: Abiraterone and increased survival in metastatic prostate cancer. N Engl J Med 2011, 364(21):1995-2005.

10. Hu R, Lu C, Mostaghel EA, Yegnasubramanian S, Gurel M, Tannahill C, Edwards J, Isaacs WB, Nelson PS, Bluemn E et al: Distinct transcriptional programs mediated by the ligand-dependent full-length androgen receptor and its splice variants in castration-resistant prostate cancer. Cancer research 2012 , 72(14):3457-3462.

11. Chan SC, Li Y, Dehm SM: Androgen receptor splice variants activate androgen receptor target genes and support aberrant prostate cancer cell growth independent of canonical androgen receptor nuclear localization signal. The Journal of biological chemistry 2012, 287(23):19736-19749.

12. Jimenez-Vacas JM, Herrero-Aguayo V, Montero-Hidalgo AJ, Gomez-Gomez E, Fuentes-Fayos AC, Leon-Gonzalez AJ, Saez-Martinez P, Alors-Perez E, Pedraza-Arevalo S, Gonzalez-Serrano $\mathrm{T}$ et al: Dysregulation of the splicing machinery is directly associated to aggressiveness of prostate cancer EBioMedicine 2020:102547. 
13. Antonarakis ES, Lu C, Wang H, Luber B, Nakazawa M, Roeser JC, Chen Y, Mohammad TA, Chen Y, Fedor HL et al: AR-V7 and resistance to enzalutamide and abiraterone in prostate cancer. N Engl J Med 2014, 371(11):1028-1038.

14. Antonarakis ES, Lu C, Luber B, Wang H, Chen Y, Zhu Y, Silberstein JL, Taylor MN, Maughan BL, Denmeade SR et al: Clinical Significance of Androgen Receptor Splice Variant-7 mRNA Detection in Circulating Tumor Cells of Men With Metastatic Castration-Resistant Prostate Cancer Treated With First-and Second-Line Abiraterone and Enzalutamide. Journal of clinical oncology : official journal of the American Society of Clinical Oncology 2017:JC02016701961.

15. Scher HI, Graf RP, Schreiber NA, Jayaram A, Winquist E, McLaughlin B, Lu D, Fleisher M, Orr S, Lowes L et al: Assessment of the Validity of NuclearLocalized Androgen Receptor Splice Variant 7 in Circulating Tumor Cells as a Predictive Biomarker for Castration-Resistant Prostate Cancer. JAMA oncology 2018.

16. Antonarakis ES, Armstrong AJ, Dehm SM, Luo J: Androgen receptor variant-driven prostate cancer: clinical implications and therapeutic targeting. Prostate cancer and prostatic diseases 2016, 19(3):231-241.

17. Li H, Wang Z, Tang K, Zhou H, Liu H, Yan L, Guan W, Chen K, Xu H, Ye Z: Prognostic Value of Androgen Receptor Splice Variant 7 in the Treatment of Castration-resistant Prostate Cancer with Next generation Androgen Receptor Signal Inhibition: A Systematic Review and Meta-analysis. European urology focus 2018, 4(4):529-539.

18. Tendulkar RD, Agrawal S, Gao T, Efstathiou JA, Pisansky TM, Michalski JM, Koontz BF, Hamstra DA, Feng FY, Liauw SL et al: Contemporary Update of a Multi-Institutional Predictive Nomogram for Salvage Radiotherapy After Radical Prostatectomy. J Clin Onco/ 2016, 34(30):3648-3654.

19. Chung JS, Wang Y, Henderson J, Singhal U, Qiao Y, Zaslavsky AB, Hovelson DH, Spratt DE, Reichert Z, Palapattu GS et al: Circulating Tumor Cell-Based Molecular Classifier for Predicting Resistance to Abiraterone and Enzalutamide in Metastatic Castration-Resistant Prostate Cancer. Neoplasia (New York, NY) 2019, 21(8):802-809.

20. Tagawa ST, Antonarakis ES, Gjyrezi A, Galletti G, Kim S, Worroll D, Stewart J, Zaher A, Szatrowski TP, Ballman KV et al: Expression of AR-V7 and ARv(567es) in Circulating Tumor Cells Correlates with Outcomes to Taxane Therapy in Men with Metastatic Prostate Cancer Treated in TAXYNERGY Clinical cancer research : an official journal of the American Association for Cancer Research 2019, 25(6):1880-1888.

21. El-Heliebi A, Hille C, Laxman N, Svedlund J, Haudum C, Ercan E, Kroneis T, Chen S, Smolle M, Rossmann C et al: In Situ Detection and Quantification of ARV7, AR-FL, PSA, and KRAS Point Mutations in Circulating Tumor Cells. Clin Chem 2018, 64(3):536-546.

22. Nakazawa M, Lu C, Chen Y, Paller CJ, Carducci MA, Eisenberger MA, Luo J, Antonarakis ES: Serial blood-based analysis of AR-V7 in men with advanced prostate cancer. Annals of oncology : official journal of the European Society for Medical Oncology / ESMO 2015, 26(9):1859-1865.

23. Zadra G, Ribeiro CF, Chetta P, Ho Y, Cacciatore S, Gao X, Syamala S, Bango C, Photopoulos C, Huang Y et al: Inhibition of de novo lipogenesis targets androgen receptor signaling in castration-resistant prostate cancer. Proceedings of the National Academy of Sciences of the United States of America 2019, 116(2):631-640.

24. Liberati A, Altman DG, Tetzlaff J, Mulrow C, Gotzsche PC, loannidis JP, Clarke M, Devereaux PJ, Kleijnen J, Moher D: The PRISMA statement for reporting systematic reviews and meta-analyses of studies that evaluate health care interventions: explanation and elaboration. PLoS medicine 2009, 6(7):e1000100.

25. Guo Z, Yang X, Sun F, Jiang R, Linn DE, Chen H, Chen H, Kong X, Melamed J, Tepper CG et al: A novel androgen receptor splice variant is up-regulated during prostate cancer progression and promotes androgen depletion-resistant growth. Cancer research 2009, 69(6):2305-2313.

26. Hörnberg E, Ylitalo EB, Crnalic S, Antti H, Stattin P, Widmark A, Bergh A, Wikström P: Expression of androgen receptor splice variants in prostate cancer bone metastases is associated with castration-resistance and short survival. PloS one 2011, 6(4):e19059-e19059.

27. Hu R, Dunn TA, Wei S, Isharwal S, Veltri RW, Humphreys E, Han M, Partin AW, Vessella RL, Isaacs WB et al: Ligand-independent androgen receptor variants derived from splicing of cryptic exons signify hormone-refractory prostate cancer. Cancer research 2009, 69(1):16-22.

28. Robinson D, Van Allen EM, Wu YM, Schultz N, Lonigro RJ, Mosquera JM, Montgomery B, Taplin ME, Pritchard CC, Attard G et al: Integrative clinical genomics of advanced prostate cancer. Cell 2015, 161(5):1215-1228.

29. Sun S, Sprenger CCT, Vessella RL, Haugk K, Soriano K, Mostaghel EA, Page ST, Coleman IM, Nguyen HM, Sun H et al: Castration resistance in human prostate cancer is conferred by a frequently occurring androgen receptor splice variant. The Journal of clinical investigation 2010, 120(8):2715-2730.

30. Plymate SR, Sharp A, de Bono JS: Nuclear Circulating Tumor Cell Androgen Receptor Variant 7 in Castration-Resistant Prostate Cancer: The Devil Is in the Detail. JAMA oncology 2018, 4(9):1187-1188.

31. Scher HI, P. GR, A. SN, Anuradha J, Eric W, Brigit M, David L, Martin F, Sarah O, Oncology LLJJ: Assessment of the Validity of Nuclear-Localized Androgen Receptor Splice Variant 7 in Circulating Tumor Cells as a Predictive Biomarker for Castration-Resistant Prostate Cancer.

32. Antonarakis ES, Lu C, Luber B, Wang H, Chen Y, Nakazawa M, Nadal R, Paller CJ, Denmeade SR, Carducci MA et al: Androgen Receptor Splice Variant 7 and Efficacy of Taxane Chemotherapy in Patients With Metastatic Castration-Resistant Prostate Cancer. JAMA oncology 2015, 1(5):582-591.

33. Onstenk W, Sieuwerts AM, Kraan J, Van M, Nieuweboer AJM, Mathijssen RHJ, Hamberg P, Meulenbeld HJ, De Laere B, Dirix LY et al: Efficacy of Cabazitaxel in Castration-resistant Prostate Cancer Is Independent of the Presence of AR-V7 in Circulating Tumor Cells. European urology 2015, 68(6):939945.

34. Scher HI, Lu D, Schreiber NA, Louw J, Graf RP, Vargas HA, Johnson A, Jendrisak A, Bambury R, Danila D et al: Association of AR-V7 on Circulating Tumor Cells as a Treatment-Specific Biomarker With Outcomes and Survival in Castration-Resistant Prostate Cancer. JAMA oncology 2016, 2(11):1441-1449.

35. Steinestel J, Luedeke M, Arndt A, Schnoeller TJ, Lennerz JK, Wurm C, Maier C, Cronauer MV, Steinestel K, Schrader AJ: Detecting predictive androgen receptor modifications in circulating prostate cancer cells. Oncotarget 2015, 10(41):4213-4223. 
36. Sieuwerts AM, Mostert B, van der Vlugt-Daane M, Kraan J, Beaufort CM, Van M, Prager WJC, De Laere B, Beije N, Hamberg P et al: An In-Depth Evaluation of the Validity and Logistics Surrounding the Testing of AR-V7 mRNA Expression in Circulating Tumor Cells. J Mol Diagn 2018, 20(3):316-325.

37. Zhu Y, Sharp A, Anderson CM, Silberstein JL, Taylor M, Lu C, Zhao P, De Marzo AM, Antonarakis ES, Wang M et al: Novel Junction-specific and Quantifiable In Situ Detection of AR-V7 and its Clinical Correlates in Metastatic Castration-resistant Prostate Cancer. Eur Urol 2018, 73(5):727-735.

38. Sharp A, Coleman I, Yuan W, Sprenger C, Dolling D, Rodrigues DN, Russo JW, Figueiredo I, Bertan C, Seed G et al: Androgen receptor splice variant-7 expression emerges with castration resistance in prostate cancer. The Journal of clinical investigation 2019, 129(1):192-208.

39. Qu F, Xie W, Nakabayashi M, Zhang H, Jeong SH, Wang X, Komura K, Sweeney CJ, Sartor O, Lee GM et al: Association of AR-V7 and Prostate-Specific Antigen RNA Levels in Blood with Efficacy of Abiraterone Acetate and Enzalutamide Treatment in Men with Prostate Cancer. Clin Cancer Res 2017, 23(3):726-734.

40. Todenhofer T, Azad A, Stewart C, Gao J, Eigl BJ, Gleave ME, Joshua AM, Black PC, Chi KN: AR-V7 Transcripts in Whole Blood RNA of Patients with Metastatic Castration Resistant Prostate Cancer Correlate with Response to Abiraterone Acetate. The Journal of urology 2017, 197(1):135-142.

41. Belderbos BPS, Sieuwerts AM, Hoop EO, Mostert B, Kraan J, Hamberg P, Van MN, Beaufort CM, Onstenk W, van Soest RJ et al: Associations between AR-V7 status in circulating tumour cells, circulating tumour cell count and survival in men with metastatic castration-resistant prostate cancer. European journal of cancer (Oxford, England : 1990) 2019, 121:48-54.

42. Morlacco A, Dal Moro F, Rangel LJ, Carlson RE, Schulte PJ, Jeffrey KR: Impact of metabolic syndrome on oncologic outcomes at radical prostatectomy Urol Oncol 2018, 36(12):528 e521-528 e526.

43. Del Re M, Biasco E, Crucitta S, Derosa L, Rofi E, Orlandini C, Miccoli M, Galli L, Falcone A, Jenster GW et al: The Detection of Androgen Receptor Splice Variant 7 in Plasma-derived Exosomal RNA Strongly Predicts Resistance to Hormonal Therapy in Metastatic Prostate Cancer Patients. European urology 2017, 71(4):680-687.

44. Takeuchi T, Okuno Y, Hattori-Kato M, Zaitsu M, Mikami K: Detection of AR-V7 mRNA in whole blood may not predict the effectiveness of novel endocrine drugs for castration-resistant prostate cancer. Research and reports in urology 2016, 8:21-25.

45. Lee CH, Ku JY, Ha JM, Bae SS, Lee JZ, Kim CS, Ha HK: Transcript Levels of Androgen Receptor Variant 7 and Ubiquitin-Conjugating Enzyme 2C in Hormone Sensitive Prostate Cancer and Castration-Resistant Prostate Cancer. The Prostate 2017, 77(1):60-71.

46. Wang S, Yang S, Nan C, Wang Y, He Y, Mu H: Expression of Androgen Receptor Variant 7 (AR-V7) in Circulated Tumor Cells and Correlation with Drug Resistance of Prostate Cancer Cells. Med Sci Monit 2018, 24:7051-7056.

47. Steinestel J, Luedeke M, Arndt A, Schnoeller TJ, Lennerz JK, Wurm C, Maier C, Cronauer MV, Steinestel K, Schrader AJ: Todenhofer T,Detecting predictive androgen receptor modifications in circulating prostate cancer cells. Oncotarget 2015.

48. Onstenk W, Sieuwerts AM, Kraan J, Van M, Nieuweboer AJ, Mathijssen RH, Hamberg P, Meulenbeld HJ, De Laere B, Dirix LY et al: Efficacy of Cabazitaxel in Castration-resistant Prostate Cancer Is Independent of the Presence of AR-V7 in Circulating Tumor Cells. European urology 2015, 68(6):939-945.

49. Zhang X, Morrissey C, Sun S, Ketchandji M, Nelson PS, True LD, Vakar-Lopez F, Vessella RL, Plymate SR: Androgen receptor variants occur frequently in castration resistant prostate cancer metastases. PloS one 2011, 6(11):e27970.

50. Saylor PJ, Lee RJ, Arora KS, Deshpande V, Hu R, Olivier K, Meneely E, Rivera MN, Ting DT, Wu CL et al: Branched chain RNA in situ hybridization for androgen receptor splice variant AR-V7 as a prognostic biomarker for metastatic castration-sensitive prostate cancer. Clinical cancer research : an official journal of the American Association for Cancer Research 2016

51. Cattrini C, Rubagotti A, Zinoli L, Cerbone L, Zanardi E, Capaia M, Barboro P, Boccardo F: Role of Circulating Tumor Cells (CTC), Androgen Receptor Full Length (AR-FL) and Androgen Receptor Splice Variant 7 (AR-V7) in a Prospective Cohort of Castration-Resistant Metastatic Prostate Cancer Patients. Cancers (Basel) 2019, 11(9).

52. Taplin ME, Antonarakis ES, Ferrante KJ, Horgan K, Blumenstein B, Saad F, Luo J, de Bono JS: Androgen Receptor Modulation Optimized for ResponseSplice Variant: A Phase 3, Randomized Trial of Galeterone Versus Enzalutamide in Androgen Receptor Splice Variant-7-expressing Metastatic Castrationresistant Prostate Cancer. European urology 2019.

53. Sharp A, Welti JC, Lambros MBK, Dolling D, Rodrigues DN, Pope L, Aversa C, Figueiredo I, Fraser J, Ahmad Z et al: Clinical Utility of Circulating Tumour Cell Androgen Receptor Splice Variant-7 Status in Metastatic Castration-resistant Prostate Cancer. European urology 2019.

54. Maillet D, Allioli N, Peron J, Plesa A, Decaussin-Petrucci M, Tartas S, Ruffion A, Crouzet S, Rimokh R, Gillet PG et al: Improved Androgen Receptor Splice Variant 7 Detection Using a Highly Sensitive Assay to Predict Resistance to Abiraterone or Enzalutamide in Metastatic Prostate Cancer Patients. Eur Urol Oncol 2019.

55. Okegawa T, Ninomiya N, Masuda K, Nakamura Y, Tambo M, Nutahara K: AR-V7 in circulating tumor cells cluster as a predictive biomarker of abiraterone acetate and enzalutamide treatment in castration-resistant prostate cancer patients. The Prostate 2018, 78(8):576-582.

56. Sieuwerts AM, Onstenk W, Kraan J, Beaufort CM, Van M, De Laere B, Dirix LY, Hamberg P, Beeker A, Meulenbeld HJ et al: AR splice variants in circulating tumor cells of patients with castration-resistant prostate cancer. relation with outcome to cabazitaxel. Mol Oncol 2019, 13(8):1795-1807.

\section{Figures}




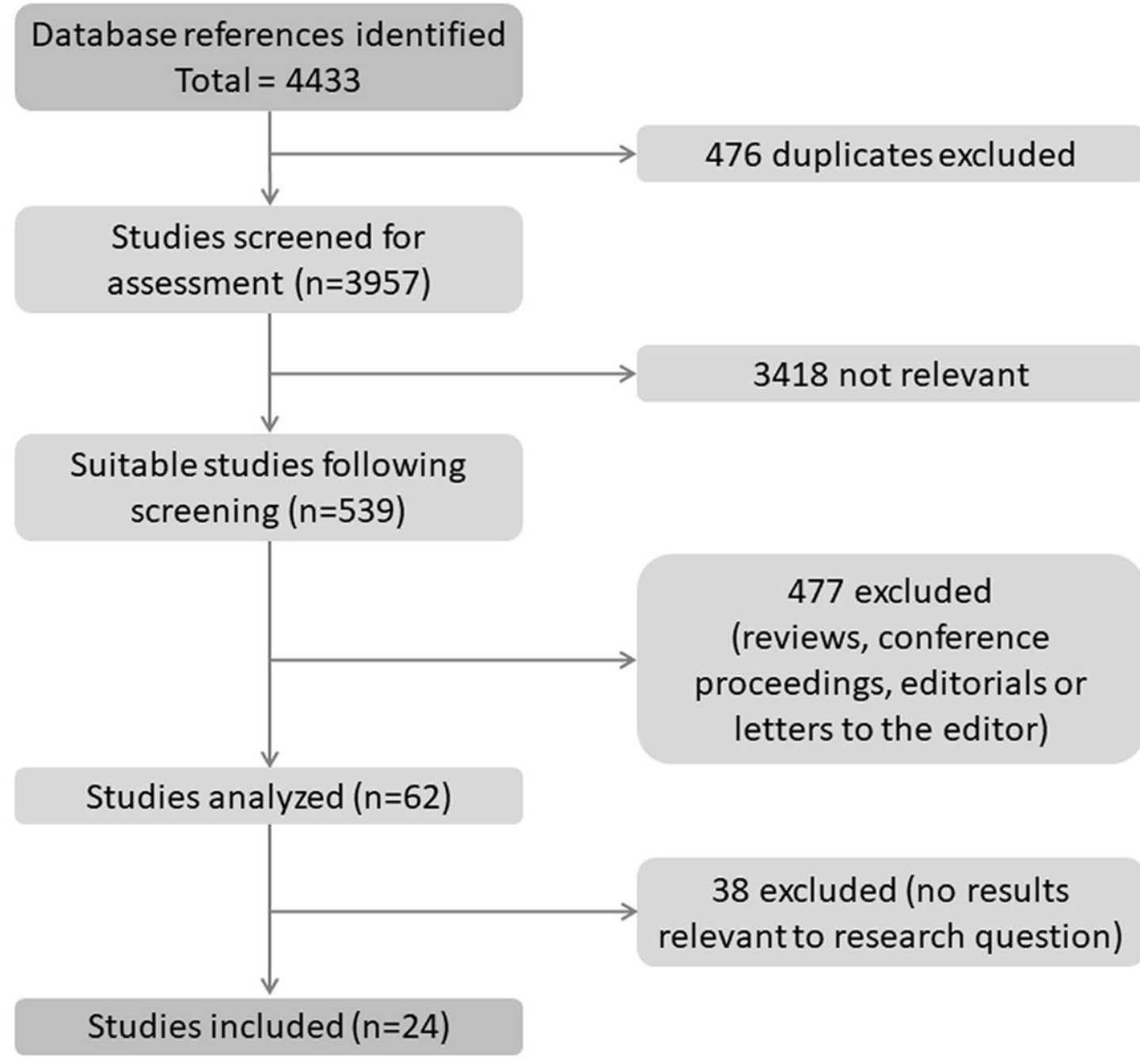

Figure 1

Study selection process.

\begin{tabular}{lrrrrr} 
& AR-V7 positive & AR-V7 negative & \\
Studv or Subgroup & Events & Total & Events & Total & Weight \\
\hline Antonarakis 2015 & 15 & 17 & 14 & 20 & $2.1 \%$ \\
Antonarakis 2017 & 30 & 36 & 116 & 166 & $9.7 \%$ \\
Antonarakis(1) 2014 & 8 & 12 & 10 & 19 & $3.6 \%$ \\
Antonarakis(2) 2014 & 3 & 6 & 19 & 25 & $5.2 \%$ \\
Chung 2019 & 12 & 20 & 8 & 17 & $4.9 \%$ \\
Del Re 2017 & 10 & 14 & 9 & 22 & $2.8 \%$ \\
El-Heliebi 2018 & 15 & 22 & 1 & 9 & $0.6 \%$ \\
Lee 2017 & 3 & 3 & 0 & 0 & \\
Maillet(1) 2019 & 6 & 9 & 17 & 32 & $3.5 \%$ \\
Maillet(2) 2019 & 14 & 23 & 9 & 18 & $5.6 \%$ \\
Nakazawa 2015 & 13 & 14 & 9 & 11 & $1.0 \%$ \\
Okegawa 2018 & 25 & 26 & 61 & 72 & $1.8 \%$ \\
Steinestel 2015 & 11 & 17 & 11 & 19 & $5.2 \%$ \\
Tagawa 2019 & 22 & 36 & 9 & 18 & $6.6 \%$ \\
Takeuchi 2016 & 16 & 20 & 15 & 23 & $3.9 \%$ \\
Taplin 2019 & 39 & 73 & 434 & 880 & $43.6 \%$ \\
& & & & & \\
Total (95\% Cl) & & 348 & & 1351 & $\mathbf{1 0 0 . 0} \%$ \\
Total events & 242 & & 742 & & \\
Heterogeneity: Chi & $=12.47, \mathrm{df}=14(\mathrm{P}=0.57) ; \mathrm{I}^{2}=0 \%$ & & \\
Test for overall effect: $Z=3.47(\mathrm{P}=0.0005)$ & & &
\end{tabular}

Odds Ratio

M-H, Fixed, 95\% Cl

$3.21[0.55,18.65]$

$2.16[0.84,5.50]$

$1.80[0.40,8.07]$

$0.32[0.05,2.00]$

$1.69[0.46,6.23]$

$3.61[0.86,15.21]$

$17.14[1.78,164.97]$

Not estimable

$1.76[0.37,8.32]$

$1.56[0.45,5.41]$

$2.89[0.23,36.87]$

$4.51[0.55,36.79]$

$1.33[0.35,5.14]$

$1.57[0.50,4.92]$

$2.13[0.53,8.58]$

$1.18[0.73,1.90]$

$1.68[1.25,2.25]$

Test for overall effect: $Z=3.47(P=0.0005)$ 
Forest plots of the proportion of Gleason scores $\geq 8$ between the group of AR-V7-positive and negative CRPC from sixteen studies. The bars indicate $95 \%$ Cls. $\mathrm{AR}-\mathrm{V} 7$ = androgen receptor splicing variant $7 ; \mathrm{Cl}=$ confidence interval; $\mathrm{OR}=$ odds ratio.

\section{A. T3/T4 stage}

\begin{tabular}{l} 
Stucty or Subgroup \\
\hline Antonarakis 2015 \\
Antonarakis(1) 2014 \\
Antonarakis(2) 2014 \\
Del Re 2017 \\
El-Heliebi 2018 \\
Lee 2017
\end{tabular}

AR-V7 positive AR-V7 negative Events Total Events

46

$4 \quad 14$

$13 \quad 22$

Total $(95 \% \mathrm{Cl})$

Total events

74

Heterogeneity: $\mathrm{Chi}^{2}=5.58, \mathrm{df}=4(\mathrm{P}=0.23) ; \mathrm{I}^{2}=28 \%$

Test for overall effect: $Z=0.45(P=0.65)$

47

\section{B. N1 stage}

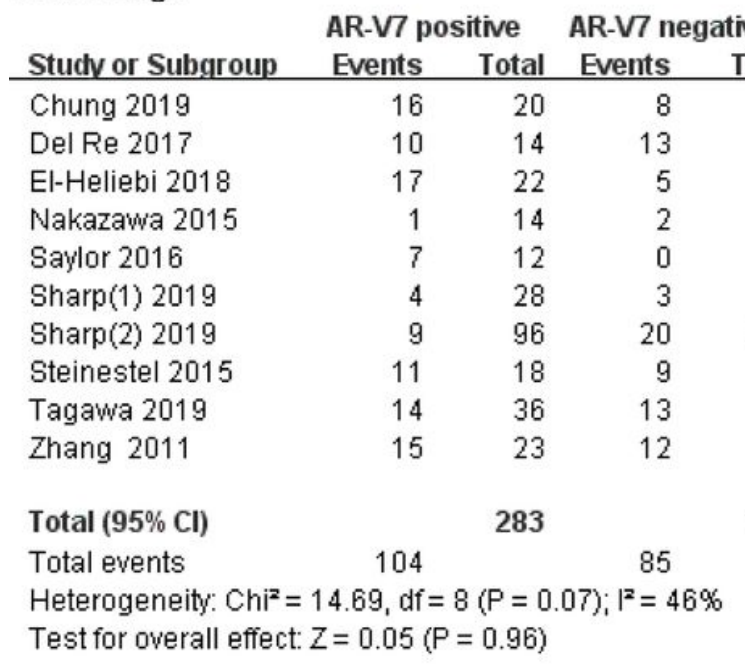
Odds Ratio

Total

Weight
$29.8 \%$
$24.6 \%$
$11.7 \%$
$30.3 \%$
$3.5 \%$

$\mathrm{M}-\mathrm{H}$, Fixed, 95\% Cl

Odds Ratio

$0.77[0.20,2.92]$

$0.79[0.18,3.41]$

$1.33[0.20,8.71]$

$0.58[0.14,2.43]$

$95100.0 \%$

$1.56[1.22,109.19]$

Not estimable

$1.16[0.60,2.24]$

Odds Ratio

Total Weight M-H, Fixed, $95 \% \mathrm{Cl}$

$17 \quad 4.0 \% \quad 4.50[1.05,19.22]$

$22 \quad 6.6 \% \quad 1.73[0.41,7.29]$

g $3.7 \% \quad 2.72[0.52,14.16]$

$11 \quad 4.8 \% \quad 0.35[0.03,4.42]$

Not estimable

$8 \quad 9.2 \% \quad 0.28[0.05,1.65]$

$181 \quad 28.9 \% \quad 0.83[0.36,1.91]$

$19 \quad 7.8 \% \quad 1.75[0.47,6.45]$

$18 \quad 24.4 \% \quad 0.24[0.07,0.84]$

$19 \quad 10.5 \% \quad 1.09[0.31,3.88]$

$304100.0 \% \quad 0.99[0.65,1.51]$

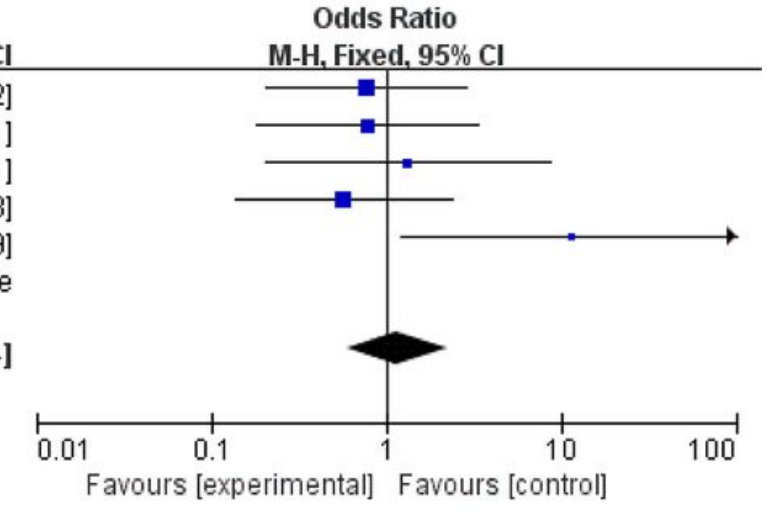

Favours [experimental] Favours [control]

\section{Figure 3}

Forest plots of T stage and $\mathrm{N}$ stage in CRPC between the group of AR-V7-positive and negative. (A) The ratio of T3/T4 stage in different AR-V7 status CRPC.

(B) The ratio of $\mathrm{N} 1$ stage in different AR-V7 status CRPC. The bars indicate $95 \% \mathrm{Cls}$. AR-V7 = androgen receptor splicing variant 7; $\mathrm{Cl}=\mathrm{confidence} \mathrm{interval;} \mathrm{OR}$ = odds ratio. 

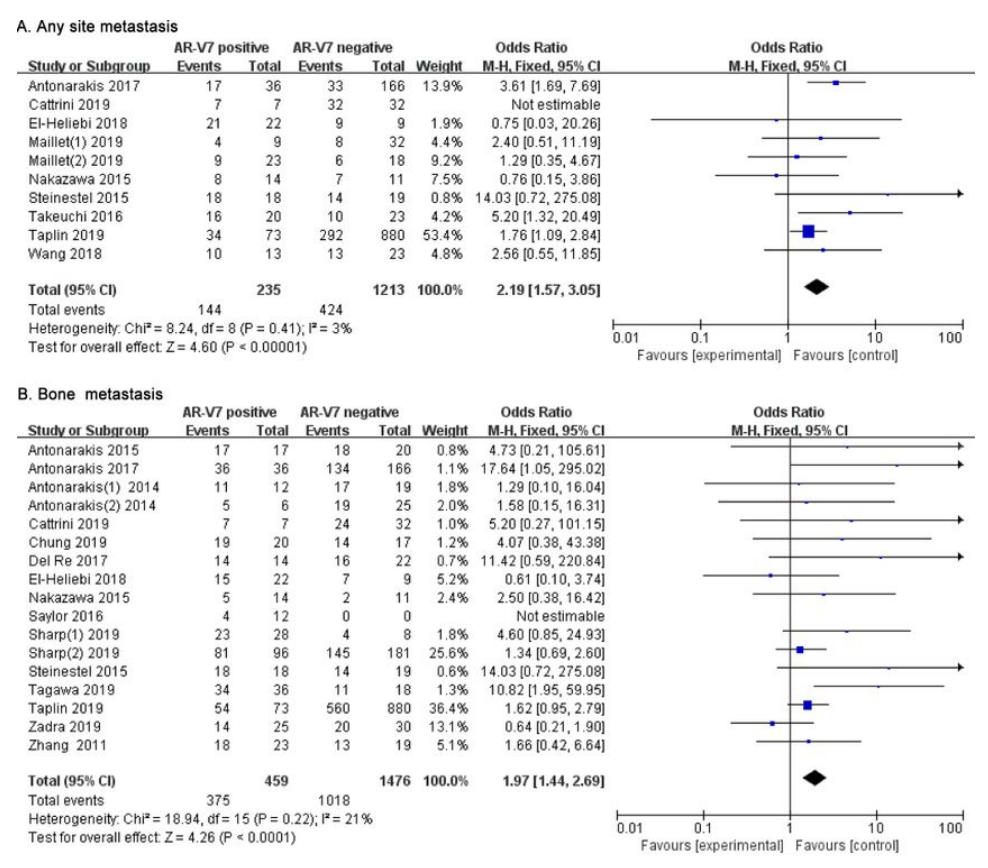

\section{Visceral metastasis ${ }_{\text {AR.V7 positive AR.V7 negative }}$}

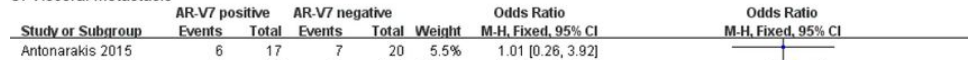
Antonarakis(1) 2014 Antonarakis(2) 201
Cattrini 2019 Chung 2019 Del Re 2017 El-Heliebi 2018 Maillet(1) 2019 Maillet(2) 2019 Okayaw 2016 Sharp(1) 2019 Sharp(2) 2019 Steinestel 2015 Tagawa 2019 Zadra 2019

Total $(95 \% \mathrm{Cl}$ ) Total events Heterogeneity. Chi $^{2}=19.67$, df $=16(P=0.24) ; P^{2}=196$ Test for overall effect $Z=1.67(P=0.09)$

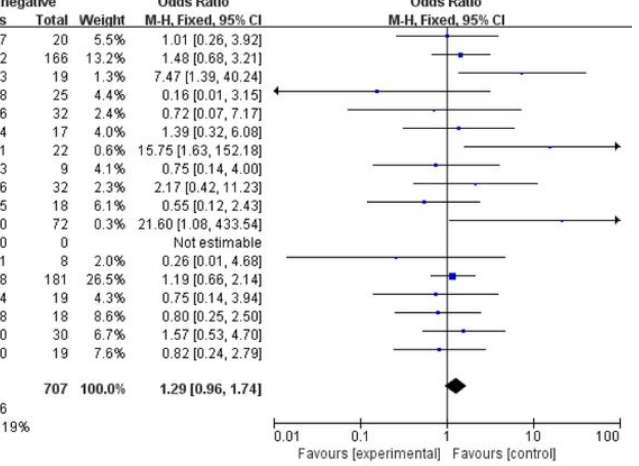

\section{Figure 4}

Forest plots of metastasis in CRPC between the group of AR-V7-positive and negative. (A) The rate of any site metastasis in different AR-V7 status CRPC. (B) The rate of bone metastasis in different AR-V7 status CRPC. (C) The rate of visceral metastasis in different AR-V7 status CRPC. The bars indicate $95 \%$ Cls. AR$\mathrm{V7}$ = androgen receptor splicing variant $7 ; \mathrm{Cl}=$ confidence interval; $\mathrm{OR}=$ odds ratio. 


\section{A. Presence of pain}

AR-V7 positive AR-V7 negative

Odds Ratio

Odds Ratio

\begin{tabular}{lrrrrrr} 
Studv or Subgroup & Events & Total & Events & Total & Weight & M-H, Fixed, 95\% Cl \\
\hline Antonarakis 2017 & 26 & 36 & 62 & 166 & $44.1 \%$ & $4.36[1.97,9.65]$ \\
Del Re 2017 & 9 & 14 & 5 & 22 & $10.0 \%$ & $6.12[1.39,26.88]$ \\
Maillet(1) 2019 & 7 & 9 & 8 & 32 & $5.6 \%$ & $10.50[1.80,61.24]$ \\
Maillet(2) 2019 & 11 & 23 & 4 & 18 & $16.8 \%$ & $3.21[0.81,12.75]$ \\
Okegawa 2018 & 6 & 26 & 8 & 72 & $23.5 \%$ & $2.40[0.74,7.74]$ \\
& & & & & & \\
Total (95\% Cl) & & $\mathbf{1 0 8}$ & & $\mathbf{3 1 0}$ & $\mathbf{1 0 0 . 0} \%$ & $\mathbf{4} .23[2.52,7.10]$ \\
Total events & 59 & & 87 & & &
\end{tabular}

Heterogeneity: $\mathrm{Chi}^{2}=2.32, \mathrm{df}=4(\mathrm{P}=0.68) ; \mathrm{I}^{2}=0 \%$

Test for overall effect: $Z=5.45$ ( $P<0.00001$ )

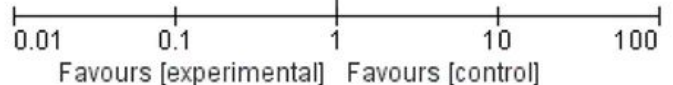

B. ECOG score $\geq 1$

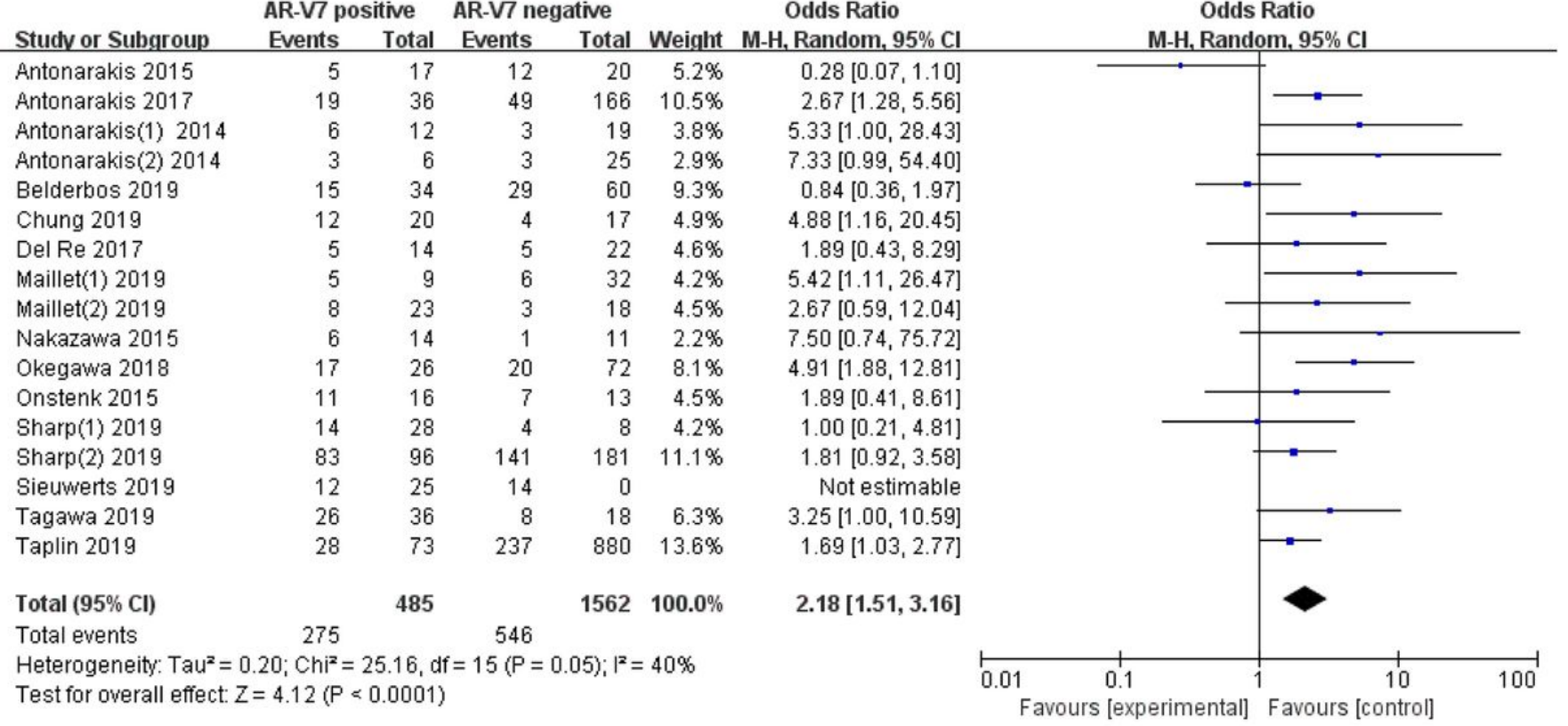

\section{Figure 5}

Forest plots of performance status in CRPC between the group of AR-V7-positive and negative. (A) The rate of pain sufferance in different AR-V7 status CRPC.

(B) The rate of ECOG score $\geq 1$ in different AR-V7 status CRPC. The bars indicate $95 \% \mathrm{Cls}$. AR-V7 = androgen receptor splicing variant $7 ; \mathrm{Cl}=\mathrm{confidence}$ interval; $\mathrm{OR}=$ odds ratio.

\section{Supplementary Files}

This is a list of supplementary files associated with this preprint. Click to download.

- supplement.docx 